DOI: $10.21802 / \mathrm{artm} .2019 .4 .12 .153$.

УДК 371.32: 575

\title{
ЗАСТОСУВАННЯ СУЧАСНИХ ПІДХОДІВ ДО ВИКЛАДАННЯ ОСНОВ ОНКОГЕНЕТИКИ ДЛЯ СТУДЕНТІВ-МЕДИКІВ
}

\section{Н.I. Кіцера}

Івано-Франківський наиіональний медичний університет, кафедра медичної біології і медичної генетики, м. Івано-Франківськ, Украӥна, Державна установа «Інститут спадкової патології НАМН Украӥни», м. Львів, Украӥна, ORCID ID: 0000-0002-6617-9336, e-mail:nkitsera@gmail.com

Резюме. Глобалізаційні процеси в сфері модернізації якості освіти та навчання зумовлюють потребу удосконалення та застосування новітніх підходів до викладання та подачі матеріалу студентам-медикам. В умовах стрімкого зростання онкологічних захворювань назріла необхідність створення інтегрованих підходів до методології ведення практичних та теоретичних дисциплін задля успішного проведення навчального процесу, який дозволятиме підготувати фахівців медичної сфери, зокрема в галузі онкології та онкогенетики. Необхідна інтеграція викладання онкогенетики на теоретичних кафедрах і створення цілісної наскрізної програми 3 подальшим продовженням на клінічних базах.

У статті проаналізовано основні сучасні інструменти щодо викладання основ онкогенетики для студентів-медиків з метою розроблення цілісної системи іії викладання в Івано-Франківському національному медичному університеті.

Ефективність та результативність організації професійної підготовки майбутніх медиків 3 онкогенетики залежить від форм і засобів освітнього процесу. Застосування інтерактивних методів навчання (ділова рольова гра, створення відеофрагментів, методики Пазли тощо) допомагають при формуванні професійних компетентностей студентів-медиків з основ онкогенетики.

Перспективи майбутніх досліджень полягають у створенні методичних рекомендацій з інтеграції викладання основ онкогенетики на всіх кафедрах університету, проведенні комплексних лекцій для студентів із залученням різних спеціалістів, ширшому впровадженні сучасних інноваційних методик викладання студентам медичних спеціальностей дисциплін в сфері онкогенетеки.

Ключові слова: онкогенетика, викладання, навчальний процес, інновації, студенти-медики.

Вступ. Згідно з даними Всесвітньої організації охорони здоров'я, кожен шостий $(9,6$ млн людей у світі) у 2018 році помер від раку. За даними Міністерства охорони здоров'я України, станом на сьогодні понад мільйон українців мають онкологічні захворювання. Щодня майже п'ять сотень людей дізнаються про свій новий невтішний діагноз. Кожного року кількість онкологічних захворювань зростає приблизно на 150 тисяч випадків. Зазначимо, що 100 тисяч людей вмирають від злоякісних новоутворень, при цьому половина 3 них на першому році захворювання. Щодо України, то кожного року діагностується більше 160 тисяч нових випадків злоякісних пухлин, майже 100 тисяч жителів вмирають від цих новоутворень, $з$ них третина померлих - це працездатне населення. Щогодини реєструється більше 20 нових випадків, а кожен другий українець вмирає від раку [1].

Згідно з Наказом Міністерства освіти та науки від 01.07.2014 р. № 1556-VII «Про вищу освіту» [2], практична підготовка студентів-медиків передбачає вивчення клінічних проявів основних захворювань, навчання умінням обстеження хворого, вміння ставити розгорнутий клінічний діагноз хворого на основі зібраної інформації, застосування методу диференціальної діагностики.
Глобалізаційні процеси в сфері модернізації якості освіти та навчання зумовлюють потребу удосконалення та застосування новітніх підходів до викладання та подачі матеріалу студентам-медикам. Відомо, що аналіз та засвоєння поданого матеріалу впродовж лекцій чи практичних занять - це уже на $50 \%$ вивчений матеріал, а решта - на власній відповідальності кожного студента, який повинен розуміти, для чого він навчається у вищому навчальному закладі (ВН3) та які завдання впродовж навчання повинен виконати.

Обгрунтування дослідження. Студентаммедикам важливо, по-перше, мати бажання та натхнення для вивчення певного переліку дисциплін, які встановлені для майбутніх лікарів, по-друге, навчатися за сучасними, інноваційними методами, якими будуть викладатися ці предмети та поглиблювати знання за допомогою різноманітних інтерактивних інструментів, поданих викладачами. В умовах сьогодення, застосування цікавих, та головне практичних інноваційних технологій викладання, набирає широкої популярності в рамках подачі нового матеріалу студентам-медикам для успішного засвоєння доволі важливого матеріалу.

Матеріали та методи. Методологічну основу статті становлять сукупність принципів, прийомів, 
загальнотеоретичних, спеціальних та міждисциплінарних методів наукового дослідження. Науковотеоретичну та методичну основу дослідження склали наукові праці та публікації вчених, матеріали наукових конференцій у сфері основ педагогіки, методів ефективного та результативного проведення освітнього процесу студентам ВНЗ, в тому числі застосування інтерактивних методів навчання.

Необхідність застосування методичного, ілюстрованого та відео-матеріалу $\epsilon$ обов'язковим атрибутом для удосконалення організації процесу навчання для студентів-медиків 5-го та 6-го курсів, на думку вчених [3].

Застосування інноваційних та практичних інструментів педагогіки $є$ тим фундаментом, який дозволяє реалізувати потенційні можливості кожного майбутнього лікаря.

Метою дослідження $є$ аналіз основних сучасних інструментів щодо викладання основ онкогенетики для студентів-медиків $з$ метою розробки цілісної системи ії̈ викладання.

Результати дослідження. Для кожного студента важливим є розуміння того, наскільки відповідально та працелюбно викладач ставиться до свого предмету i, також, до своїх студентів. Це дзеркально відображається у рівні підготовки викладача до кожної лекції чи практичного заняття. Не виключенням $є$ i працівники медичних університетів, що подають найважливішу інформацію, яку майбутні лікарі будуть застосовувати на практиці. По суті, деякі рішення майбутніх фахівців залежать від рівня кваліфікації викладачів медичної сфери. Тому викладачам слід подавати переважно складний матеріал у максимально цікавій, інтерактивній формі.

Щодо викладання онкогенетики, то вже на першому курсі в Івано-Франківському національному медичному університеті (ІФНМУ) при читанні тем лекцій та проведенні практичних занять «Методи генетики людини», «Спадкові хвороби» наводяться родоводи осіб, обтяжених онкологічними захворюваннями, пропонується розрахувати ризик такої патології у нащадків. Роль мутагенних чинників довкілля в активації онкогенів розглядається на лекціях і практичних заняттях з екології людини. При цьому використовуються відповідні ситуаційні задачі, рольові ігри, демонструються відеофрагменти. Забезпечення всіх навчальних кімнат телевізорами, підключення до мережі головного сайту ІФНМУ дозволяє проводити тестування засвоєного матеріалу не лише українською, а й англійською мовами.

3 метою поглиблення знань 3 основ онкогенетики до тематичного плану елективного курсу за вибором «Сучасні проблеми молекулярної біології» включено питання про молекулярні основи онкологічних захворювань. На одному із засідань студентського наукового гуртка обговорюється реферат, підготовлений студентами на відповідну тему. На кафедрах патологічної анатомії та патологічної фізіології звертається увага на патологічні зміни в органах i системах онкохворих і механізми їх виникнення. Водночас необхідна інтеграція викладання онкогенетики на теоретичних кафедрах і створення цілісної наскрізної програми 3 подальшим продовженням на клінічних базах.

Водночас в умовах стрімкого зростання онкологічних захворювань назріла необхідність створення інтегрованих підходів до методології ведення практичних та теоретичних дисциплін задля успішного проведення навчального процесу, який дозволятиме підготувати фахівців медичної сфери, зокрема в галузі онкології та онкогенетики. Найбільша увага до викладання основ онкогенетики в ІФНМУ приділяється на п’ятому курсі вивченню медичної генетики. При цьому застосовується проблемний метод викладання [4], що полягає у створенні проблемної ситуації, яку необхідно проаналізувати, визначити основні фактори впливу та прийняти рішення. Зокрема, при вивченні основ онкогенетики, як і різних тем дисципліни, розроблено завдання щодо визначення родоводу, детального розбору випадків, збирання клінікогенеалогічного анамнезу пацієнта, який $є$ онкохворим. Такі завдання студенти можуть вирішувати як індивідуально, так і у невеликих групах.

Відповідно до психології людини, зорові аналізатори набагато краще сприймають нову інформацію, оскільки людське око може охопити мільйони біт на секунду, а вухо сприймає лише декілька десятків тисяч [3]. Наш досвід показав, що доцільним є розв'язання таких завдань у групі, оскільки це розвиває командні здібності, супроводжується дискусіями, адже кожен відчуває причетність до завдання, що необхідно освоїти кожному майбутньому медичному працівнику. Дослідження, представлені у роботі [5], переконливо підтверджують актуальність застосування практичного підходу для викладання студентам-медикам, що ілюструє запропонована авторами схема (рис. 1).

Наявність сучасної, інноваційної університетської клініки в ІФНМУ дає змогу на післядипломному етапі інтернам разом із викладачами змоделювати можливі ситуації щодо випадків онкопатології. Поглиблене вивчення онкогенетики продовжується щорічно на базі кафедри медичної біології і медичної генетики з клінічними ординаторами.

Також важливим елементом при викладанні для студентів-медиків є організація навчального процесу із залученням викладачів з інших ВН3, лікарів, науковців в наш університет, що забезпечує підвищення рівня викладання онкогенетики і сприяє кращій інтеграції в міжнародний навчальний простір. До прикладу, в ІФНМУ читали цікаві лекції професори, які були запрошені з інших ВНЗ. Традиційними стали щомісячні вебінари із серії «Елементи тератології в клінічній практиці», у яких беруть участь викладачі, інтерни, студенти. У вересні 2019 року проведений четвертий 3 них. Організатором виступає впродовж багатьох років професор В. Вертелецький (США), який прочитав першу лекцію для студентів, лікарів і викладачів в ІФНМУ.

Наступним елементом $є$ підвищення освітнього рівня викладачів шляхом різноманітних програм стажування та навчання у закордонних медичних закладах та університетах. Невід'ємною складовою є також проведення всеукраїнських та міжнародних конференцій для викладачів. Також істотним 
доповненням є участь у тренінгах, грантах та інших програмах. Тобто, викладачі, які навчають студентів- медиків, повинні систематично підвищувати свою кваліфікацію.

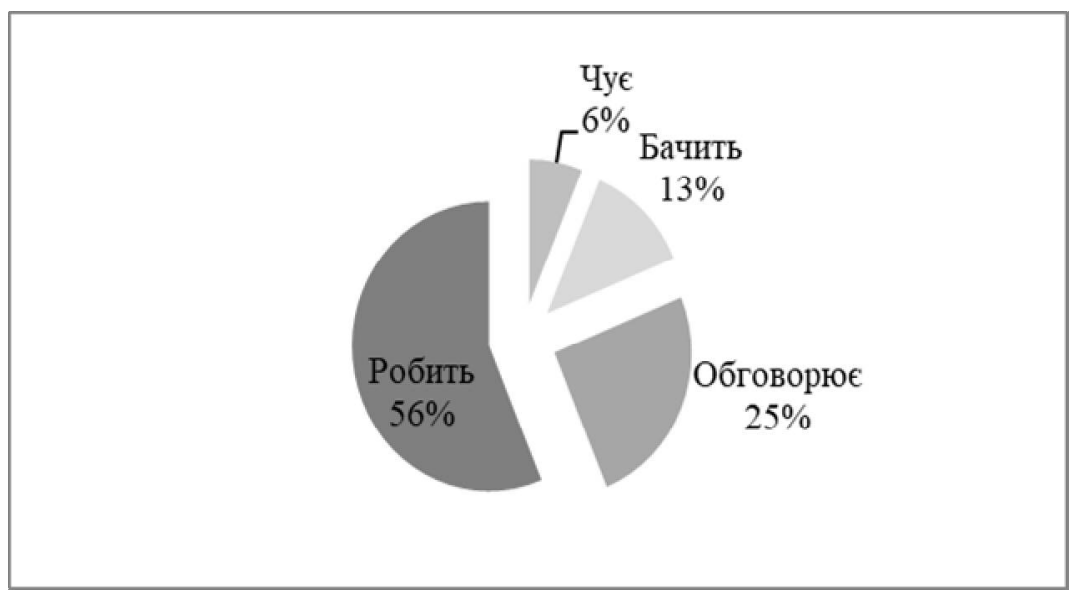

Рис. 1. Відсоткове відношення, яке згідно із засадами психології вказус на те, як середньостатистичний студент запам'ятовус інформацію та засвоюс матеріал [5]

Для об'єктивної оцінки навчального процесу і кожного викладача студентів залучають до розробки анкет із ключовими питаннями. У ІФНМУ неодноразово проводилися подібні анкетування студентським парламентом, у яких студенти оцінювали проведення лекцій, практичних занять. Студент-медик, який перебуває на фінішній прямій і незабаром буде у статусі випускника медичного університету, міг підсумувати і оцінити рівень викладання та самого викладача загалом, відповідаючи на питання анонімно. Таке дослідження надає достовірну інформацію щодо того, на які моменти слід звернути особливу увагу, аби усунути певні проблеми та покращити рівень викладання.

Наші подальші кроки полягають у застосуванні інтерактивного інструменту для вивчення нового матеріалу - дидактичної методики Пазли (Jigsaw). Така методика поділена на дві фази. Це чудовий інструмент для успішного та швидкого освоєння об'ємного матеріалу. У першій фазі необхідно поділити групу на підгрупи. Оптимальна кількість підгруп - три. Кожна підгрупа отримує різні частини загальної теми. Усі учасники підгруп повинні обговорити поданий фрагмент, вони визначають лідера, який буде представляти підгрупу. У наступній фазі лідер обирає близько п'яти найважливіших моментів iз фрагменту та у відповідній послідовності кожен лідер почергово представляє свій фрагмент. У кінці заняття кожен студент може уточнити та знайти відповіді на питання шляхом обговорення із викладачем та 3 метою підсумування нової теми. Таким чином, колективна робота студентів-медиків дозволяє легше засвоїти матеріал та добре зрозуміти істотні моменти. На кафедрі онкології, де $є$ змога працювати 3 онкохворим - пацієнтом, можна застосувати педагогічний інструмент «риб'ячий скелет» (Fishbone).

Обговорення результатів. На сьогодні більшість медичних навчальних закладів, а це: 14 університетів, 130 коледжів, 3 академії післядипломної освіти та 4 медичних факультетів у класичних уні- верситетах [6] - не повністю забезпечені відповідним матеріальним і фінансовим потенціалом для проведення практичних занять. Проте Міністерством охорони здоров'я України розроблена стратегія розвитку медичної освіти впродовж 10 років. Вона передбачає впровадження нових міжнародних стандартів медичної освіти, введення абсолютно нового кваліфікаційного іспиту, встановлення вищого прохідного балу для майбутніх студентів-медиків та, найважливіше, викладачі, як фундамент кожного університету, матимуть змогу підвищувати свою кваліфікацію в різних закладах Свропи.

Роботи багатьох учених присвячені аналізу використання та впровадження сучасних методів інтенсифікації та модернізації викладання різних дисциплін у медичних університетах [7-10]. Зокрема, конкретні методи вивчення онкології визначені у праці Голотюка В. В. [11], основна увага у якій зосереджена на необхідності підготовки спеціаліста, здатного здійснити диференційно-діагностичний пошук 3 метою вирішення професійних завдань, надання допомоги та проведення заходів задля збереження життя пацієнтів. Важливим є те, що автор звертає увагу на необхідність розвитку так званої «онкологічної настороженості» у медичних фахівців у процесі навчання задля своєчасного реагування на виявлені симптоми захворювань [7]. Саме таку мету можливо реалізувати, на думку інших авторів, при застосуванні не лише традиційних підходів у викладанні онкології $[4$, с.1], а й при використанні інформативних та інформаційно-описових, предметних, цільових, діалогових, імітаційно-ігрових, змістово-процесуальних, особистісно орієнтованих, діяльнісних, компетентнісних та інших [9, с.228].

Викладачам вищих навчальних закладів (ВН3) необхідно усвідомлювати власну відповідальність за належне та відповідне виконання роботи, яка полягає у передачі власних знань і навичок за допомогою різноманітних інструментів навчання та розроблених методологій провідними спеціалістами 
задля випуску достойних і кваліфікованих фахівців. Серед професій, які потребують особливої уваги в цій сфері, є майбутні лікарі $[4,6,11]$.

Такий підхід, як розв'язання різних завдань у групі, забезпечує задоволення потреб студентівмедиків у сфері поглиблення знань та вмінь; відчуття відповідальності за зміст і при прийняті рішення щодо поставленого завдання; постійну комунікацію із провідними лікарями-експертами у сфері онкогенетики; передавання досвіду щодо попередніх історій хвороб пацієнтів. Основними перевагами цього методу $є$ те, що подібні заняття цікаві, активні, полегшують навчання, мотивують студентів-медиків, поєднують різні стилі навчання, про що свідчать засади психології [5].

На сьогодні інформативний підхід, який полягає в передачі інформації студентам на лекції та опитуванні студентів на основі лекційного або додатково вивченого матеріалу, максимально застосовується при викладанні медичних дисциплін у більшості вищих навчальних закладів України.

Перспективи майбутніх досліджень полягають у створенні методичних рекомендацій з інтеграції викладання основ онкогенетики на всіх кафедрах ВНЗ, проведенні комплексних лекцій для студентів із залученням різних спеціалістів, ширшому впровадженні сучасних інноваційних методик викладання студентам медичних спеціальностей дисциплін в сфері онкогенетики.

Висновки. Ефективність та результативність організації професійної підготовки майбутніх медиків 3 основ онкогенетики залежить від форм і засобів освітнього процесу. Застосування інтерактивних методів навчання (ділова рольова гра, створення відеофрагментів, методики Пазли тощо) допомагають при формуванні професійних компетентностей студентівмедиків $з$ основ онкогенетики. Інтеграція викладання останньої може бути забезпечена при створенні наскрізної програми для теоретичних і клінічних дисциплін.

Принципи поєднання особистісних позицій та професійних якостей із взаємною співпрацею 3 викладачем $\epsilon$ основною складовою формування вмінь, знань студентів для ефективного виконання ними майбутніх професійних обов'язків, сприяє високому рівню їх внутрішньої мотивації до навчання. Підвищення кваліфікації викладачів різними доступними формами сприяє підготовці спеціалістів на міжнародному рівні.

\section{References:}

1. Ofitsiynyy sayt Ministerstva okhorony zdorovya Ukrayiny. VOOZ: Zdorovyy sposib zhyttya do 50\% znyzhuye ryzyk raku vid 2 kvitnia, 2019. Rezhym dostupu: https://moz.gov.ua/article/news/vooz-zdorovijsposib-zhittja-do-50-znizhue-rizik-raku.

2. Nakaz MON Ukrainy vid 01.07.2014. № 1556-VII «Pro vyshchu osvitu».

3. Bondarenko IM, Asyeyev OI, Zavizion VF, Mashtaler VYe, Kyslytsyna VS, Dmytrenko KO. Osnovy vykorystannya tekhnichnykh zasobiv navchannya $\mathrm{V}$ protsesi vykladannya onkolohiyi u studentiv medychnoho fakultetu. Upravlinnya $\mathrm{v}$ osviti: zbirnyk materialiv $\mathrm{V}$
Mizhnarodnoyi naukovo-praktychnoyi konferentsiyi, 1416 kvitnya 2011. Instytut innovatsiynykh tekhnolohiy i zmistu osvity [ta inshi]. L'viv : Vydavnytstvo Lvivs'koyi politekhniky, 2011. P.38-39.

4. Zavizion VF. Suchasni pidkhody do vykladannya onkolohiyi yak osnova vdoskonalennya navchal'noho protsesu. Medychni perspektyvy, 2012; 17, 1: 12-18.

5. Suchasni informatsiyni tekhnolohiyi ta innovatsiyni metodyky navchannya $u$ pidhotovtsi fakhivtsiv: metodolohiya, teoriya, dosvid, problemy. Zb. nauk. pr. Vypusk 40 / Redkol.: IA Zyazyun (holova) ta in. Kyyiv-Vinnytsya: TOV firma «Planer», 2014. P. 491.

6. Stratehiya rozvytku medychnoyi osvity vid 13 lystopada, 2018. Rezhym dostupu: http://moz.gov.ua/strategija-rozvitku-medichnoi-osviti.

7. Boychuk O. Suchasni psykholoho-pedahohichni vymohy do vykladacha vyshchoho medychnoho navchal'noho zakladu. Osvitolohichnyy dyskurs, 2018; 12:20-21.

8. Isayeva OS. Rozvytok tvorchykh umin studentiv vyshchykh medychnykh navchalnykh zakladiv. Pedahohika ta psykholohiya, 2013; 44:57-65.

9. Shyrmova TYe. Porivnyalna kharakterystyka kompetentnisnoho ta tradytsiynoho pidkhodiv $u$ navchanni. Mizhnarodnyy zbirnyk naukovykh prats Univerzitna Kniznica, Preshovskyy un-t, Slovachchyna, 2017. P.228-233.

10. Lucas JL, Blazek MA, Riley AB. The lack of representation of educational psychology and school psychology in introductory psychology textbooks. Educational Psychology, 2005; 25:347-351.

11. Holotyuk VV. Deyaki aspekty praktychnooriyentovanoho vykladannya onkolohiyi dlya likarivinterniv. Halyts'kyy likars'kyy visnyk, 2013; 20, 3:1-7.

\section{УДК 371.32: 575 \\ ПРИМЕНЕНИЕ СОВРЕМЕННЫХ ПОДХОДОВ К ПРЕПОДАВАНИЮ ОСНОВ ОНКОГЕНЕТИКИ ДЛЯ СТУДЕНТОВ-МЕДИКОВ}

\section{Н.И. Кицера}

Ивано-Франковский национальный медицинский университет, кафедра медицинской биологии и медииинской генетики, г. Ивано-Франковск, Украина, Государственное учреждение «Институт наследственной патологии АМН Украины»», г. Львов, Украина, ORCID ID: 0000-0002-6617-9336, e-mail: nkitsera@gmail.com

Резюме. Глобализационные процессы в сфере модернизации качества образования и обучения обусловливают необходимость совершенствования и применения новых подходов к преподаванию и подачи материала студентам-медикам. В условиях стремительного роста количества онкологических заболеваний назрела необходимость создания интегрированных подходов к методологии ведения практических и теоретических дисциплин для успешного проведения учебного процесса, который позволит подготовить специалистов медицинской сферы, в частнос- 
ти в области онкологии и онкогенетики. Необходима интеграция преподавания онкогенетики на теоретических кафедрах и создание целостной сквозной программы с последующим продлением на клинических базах.

В статье проанализированы основные современные инструменты по преподаванию основ онкогенетики для студентов-медиков при разработке целостной системы еe преподавания в ИваноФранковском национальном медицинском университете.

Эффективность и результативность организации профессиональной подготовки будущих медиков из онкогенетики зависит от форм и средств образовательного процесса. Применение интерактивных методов обучения (деловая ролевая игра, создание видеофрагментов, методики Пазлы и т.д.) помогают при формировании профессиональных компетенций студентов-медиков из основ онкогенетики.

Перспективы будущих исследований заключаются в создании методических рекомендаций по интеграции преподавания основ онкогенетики на всех кафедрах университета, проведении комплексных лекций для студентов с привлечением различных специалистов, в более широком внедрении современных инновационных методик преподавания студентам медицинских специальностей дисциплин в сфере онкогенетики.

Ключевые слова: онкогенетика, преподавание, учебный процесс, инновации, студенты-медики.

\section{UDC 371.32: 575 \\ APPLICATION OF MODERN APPROACHES TO TEACHING THE BASICS OF ONCOGENETICS FOR MEDICAL STUDENTS}

\section{N.I. Kitsera}

Ivano-Frankivsk National Medical University, Department of Medical Biology and Medical Genetics, IvanoFrankivsk, Ukraine,

Institute of Hereditary Pathology, National Academy of Medical Sciences of Ukraine", Lviv, Ukraine,

ORCID ID: 0000-0002-6617-9336,

e-mail:nkitsera@gmail.com

Abstract. Global processes in the area of modernization of quality of education and training necessitate improvement and application of the newest approaches to teaching and submission of material to medical students. At the same time, with the rapid growth of oncological diseases, there is a needing of integrated approaches to the methodology of conducting practical and theoretical disciplines in order to successful educational process, which will allow to train specialists in the medical area of oncology and oncogenetics. The application of innovative and modern pedagogical tools is the foundation that allow the realization of potential opportunities of every future doctor. At the same moment, integration of the teaching of oncogenetics at theoretical departments and the creation of a comprehensive end-to-end program with further continuation on clinical bases.

The article analyzed the main modern tools for teaching the basics of oncogenetics for medical students to develop a holistic system of teaching it in the IvanoFrankivsk National Medical University.

The most attention of teaching the basics of oncogenetics in the Ivano-Frankivsk National Medical University (IFNMU) is devoted on the fifth course in study of the basics of oncogenetics. This applies a method of teaching, which is to create a problematic situation that needs to be analyzed, to identify the main factors of influence and to make a decision. In fact, in the study of oncogenetics, as well as various subjects of the discipline, the task of determining the pedigree, the detailed analysis of cases, the collection of medical history of the patient, who has a malignant tumor in anamnesis. Such tasks can be solved by students both individually and in small groups.

Our experience has shown that it is advisable to solve these tasks in a group, because it develops teamwork which, is accompanied by discussions, because everyone is involved in this task. Obviously, it is useful for master every future healthcare provider. This way ensures that the needs of medical students in the area of knowledge and skills are met; a sense of responsibility for the content and decisions taken on that task; ongoing communication with leading experts in the area of oncogenetics; sharing experiences with patients' previous case histories. The presence of a modern, innovative university clinic at IFNMU allows at the postgraduate stage interns together with teachers to simulate possible situations in cases of oncopathology. The deep studing of the basics of oncogenetics continues every year at the Department of Medical Biology and Medical Genetics with clinical residencies.

The effect and result of the organization of professional training of future oncogenetics physicians depends on the forms and means of the educational process. The use of interactive teaching methods (business role-playing, video creation, puzzles, etc.) help with shaping the professional competencies of medical students on the basics of oncogenetics. Integration of teaching of the latter can be ensured at creation of the through-program for theoretical and clinical disciplines.

Prospects for future research will create methodological recommendations for the integration of teaching the basics of oncogenetics in all departments of the University, conducting complex lectures for students with the involvement of different specialists, wider introduction of modern innovative teaching methods for students of medical specialties of discipline in the area of oncogenetics.

Keywords: oncogenetics, teaching, educational process, tools, medical students. 